\title{
Relationship Of Role Conflict And Stress With Performance Of Employees At Seluma Timur District Police Office Seluma Regency
}

\section{Hubungan konflik peran dan stres dengan kinerja pegawai pada kantor polsek kecamatan seluma timur Kabupaten seluma}

\author{
Ngatimin 1); Ahmad Soleh2); Abdul Rahman 2) \\ 1)Study Program of Management Faculty of Econimic, Universitas Dehasen Bengkulu \\ 2) Department of Management, Faculty of Economic, Universitas Dehasen Bengkulu \\ Email: ${ }^{1)}$ ngatiminnaswa@gmail.com; ${ }^{2)}$ ahmadsolehse81@yahoo.co.id; ${ }^{3)}$ abdulrahman@unived.ac.id
}

\begin{abstract}
How to Cite :
Ngatimin., Soleh, A., Rahman, A. (2022). Relationship Of Role Conflict And Stress With Performance Of Employees At Seluma Timur District Police Office Seluma Regency. Jurnal Ekonomi Manajemen Akuntansi Dan Keuangan, 3(1). DOI: https://doi.org/10.53697/emak.v3i1
\end{abstract}

\section{ARTICLE HISTORY}

Received [22 Desember 2021]

Revised [30 Desember 2021]

Accepted [10 Januari 2022]

\section{KEYWORDS}

Role Conflict, Work Stress, Performance

This is an open access article under the $C C-B Y$-SA license

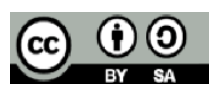

\begin{abstract}
ABSTRAK
Tujuan penelitian ini adalah untuk mengetahui hubungan konflik peran dan stress dengan kinerja pegawai pada Kantor Polsek Kecamatan Seluma Timur Kabupaten Seluma. Sampel dalam penelitian ini sebanyak 32 orang pegawai pada Kantor Polsek Seluma. Teknik pengambilan sampel adalah sensus. Pengumpulan data menggunakan kuesioner dan metode pengumpulan data menggunakan kuesioner dan metode analisis yang digunakan adalah korelasi spearman rank dan uji hipotesis dengan uji t. Hasil penelitian menunjukkan Konflik peran memiliki hubungan yang rendah dan negatif dengan kinerja pegawai pada Kantor Polsek Kecamatan Seluma Timur Kabupaten Seluma dengan nilai korelasi sebesar -0.403, berarti bahwa semakin tinggi konflik peran maka akan semakin menurun kinerja pegawai Kantor Polsek Kecamatan Seluma Timur Kabupaten Seluma. Hasil ini diperkuat dengan hasil uji hipotesis bahwa thitung sebesar $-2,411$ bernilai negative dan dilakukan pengujian hipotesis dari sisi kiri kurva maka thitung jatuh di area $\mathrm{HO}$ ditolak, dengan demikian Ha diterima. Dengan demikian hasil hipotesis adalah $\mathrm{H} 01$ ditolak dan Ha1 diterima. Artinya konflik peran mempunyai hubungan yang signifikan dengan kinerja pegawai pada Kantor Polsek Kecamatan Seluma Timur Kabupaten Seluma. Stres kerja memiliki hubungan yang sangat rendah dan negatif dengan kinerja pegawai pada Kantor Polsek Kecamatan Seluma Timur Kabupaten Seluma, dengan nilai korelasi sebesar -0,468, berarti semakin tinggi stres kerja maka akan semakin menurun kinerja pegawai pada Kantor Polsek Kecamatan Seluma Timur Kabupaten Seluma. Hal ini diperkuat dengan hasil uji hipotesis diketahui bahwa thitung sebesar $-2,901$ bernilai negative dan dilakukan pengujian hipotesis dari sisi kiri kurva maka thitung jatuh di area $\mathrm{HO}$ ditolak, dengan demikian $\mathrm{Ha}$ diterima. Artinya stres kerja mempunyai hubungan yang signifikan dengan kinerja pegawai pada Kantor Polsek Kecamatan Seluma Timur Kabupaten Seluma
\end{abstract}

\section{ABSTRACT}

The purpose of this study was to determine the effect of motivation and job satisfaction simultaneously on employee productivity at PT. Four Lawang 
Agro Perkasa in Empat Lawang Regency. The sample in this study were employees at PT. Four Lawang Agro Perkasa as many as 35 people. Collecting data using a questionnaire and the analytical method used is multiple linear regression, determination test and hypothesis testing. The results of the regression analysis show $Y=1.501+0.380 X 1+0.603 \times 2+$ 5.900 this describes a positive regression direction, meaning that there is a positive influence between $X 1$ (motivation) and X2 (job satisfaction) on work productivity $(Y)$. Means that if the variables of motivation and job satisfaction increase, it will increase work productivity. The value of the coefficient of determination is 0.590 . This means that $X 1$ (motivation) and $X 2$ (job satisfaction) affect work productivity (Y) by 59\% while the remaining $41 \%$ is influenced by other variables not examined in this study. The test results for the $X 1$ variable (motivation) show the tcount value is greater than ttable at 2,424 > 1,693 and a significance value of $0.021<0.05$. Because tcount $>$ ttable and the significance value is less than 0.05 , then $\mathrm{HO}$ is rejected and $\mathrm{Ha}$ is accepted. This means that X1 (motivation) has a significant influence on work productivity $(Y)$ of employees at PT. Four Lawang Agro Perkasa in Empat Lawang Regency. The test results for the X2 variable (job satisfaction) show the tcount value is greater than ttable at $3.258>1.693$ and a significance value of $0.003<0.05$. Because tcount $>$ ttable and the significance value is less than 0.05, $\mathrm{HO}$ is rejected and $\mathrm{Ha}$ is accepted. This means that X2 (job satisfaction) has a significant effect on work productivity $(Y)$ of employees at PT. Four Lawang Agro Perkasa in Empat Lawang Regency. The value of Fcount $>$ Ftable $(22,986>3,29)$ with a significant value of $0.000<0.05$ indicates that simultaneously $\times 1$ (motivation) and X2 (job satisfaction) have a significant effect on work productivity (Y) of employees at PT. Four Lawang Agro Perkasa in Empat Lawang Regency.

\section{PENDAHULUAN}

Perhatian sebuah instansi terhadap manajemen sumber daya manusia menjadi hal yang sangat menarik dipelajari karena posisinya yang sangat penting dan terkait dengan kinerja. Hakikat sumber daya manusia yang dipandang sebagai harta instansi merupakan suatu upaya pengintegrasian antara pemenuhan kebutuhan pegawai dengan pencapaian kinerja yang optimal. Selain itu pengelolaan sumber daya manusia yang baik mempunyai beberapa fungsi operasional, salah satu diantaranya adalah pemeliharaan yang menitikberatkan pada pemeliharaan kondisi fisik dan non fisik pegawai yaitu keselamatan, kesehatan kerja dan kesejahteraan pegawai serta pemeliharaan sikap menyenangkan yaitu terciptanya sebuah hubungan harmonis.

Konflik yang timbul diakibatkan perbedaan persepsi maupun tujuan antara nilainilai yang dianut oleh pribadi pegawai dengan sistem manajemen kinerja yang baru, dapat dindikasikan bahwa sebagian pegawai menentang adanya perubahan. Hal ini dikarenakan mereka takut ketinggalan akan pemahaman jenis tugas dan pekerjaan yang baru pula yang bisa menyebabkan mereka tersisih bukan saja dari pekerjaannya bahkan jabatan yang dimilikinya saat ini. Tuntutan untuk berubah juga menimbulkan pertentangan karena dianggap oleh pegawai sebagai hal yang merepotkan. Dalam perubahan tersebut mereka dipaksa harus belajar cara kerja atau prosedur baru yang memerlukan ketekunan dan tidak seenak cara kerja yang lama yang sudah biasa dilaksanakan, seperti mengharuskan pegawai mempelajari dan memahami sistem IT yang baru, pengoperasian komputer, dan mengikuti ujian sertifikasi manajemen risiko bagi pejabat/pemimpin seksi.

Manajemen kinerja yang terukur pada setiap unit kerja yang kemudian dibreak down kepada setiap seksi yang kemudian turun ke level terkecil yaitu 
pegawai membuat setiap pegawai dipaksa untuk keluar dari kondisi nyaman (comfort zone) kepada kondisi dan situasi kerja yang penuh tantangan dan kompetitif. Dalam pelaksanaannya konflik yang timbul terjadi antara unit kerja dan antar seksi, karena beranggapan bahwa seksi atau bagian kerja merekalah yang paling memiliki target yang terlalu besar dan beranggapan seksi lain memiliki target yang terlalu kecil, terjadi kecumburuan dan rasa ketidakadilan oleh pegawai.

Fenomena yang terjadi saat ini pada kantor Polsek Kecamatan Seluma Timur Kabupaten Seluma adalah menurunnya kinerja pegawai yang disebabkan karena tingkat stress dalam bekerja yang tinggi. Hal ini dapat dilihat dari banyaknya pekerjaan yang harus diselesaikan tepat waktu, selain itu petugas penertiban juga harus dilakukan dimana-mana. Apalagi pada saat Pandemi Covid 19 ini, tingginya tingkat penertiban yang harus dilakukan oleh pegawai Polsek Kecamatan Seluma sehingga dapat menciptakan stress dalam bekerja. Hal lain juga terjadi dalam konflik peran, permasalahan yang terjadi adalah adanya peran ganda atau perangkapan tugas yang harus diselesaikan oleh satu orang. Seperti pegawai yang bertugas menerima laporan dari masyarakat terkadang juga harus keluar ikut melakukan penertiban.

\section{LANDASAN TEORI}

\section{Manajemen Sumber Daya Manusia}

Peranan manusia dalam suatu perusahaan semakin di yakini kepentingannya. Tujuan perusahaan tidak mungkin akan terwujud tanpa peran aktif dari manusia yang mengelola perusahaan. Perusahaan tidak akan berjalan tanpa adanya peran serta sumber daya manusia, meskipun sudah ada teknologi yang serba otomatis. Kemajuan teknologi tidak akan menggeser peran sumber daya manusia secara keseluruhan dalam perusahaan karena ada hal-hal yang tidak dapat dilakukan oleh teknologi.

Manusia merupakan sumber daya yang berbeda dengan sumber daya yang lainnya, karena manusia mempunyai kemampuan berpikir, perasaan dan tingkah laku yang berbeda, karena itu diperlukan kemampuan yang baik dalam manajemen sumber daya manusia agar sumber daya manusia yang dikelola dengan baik dan efisien. Menurut Handoko (2017: 3) Manajemen sumber daya manusia adalah terdiri dari penarikan, seleksi, pengembangan, penggunaan, dan pemeliharaan sumber daya manusia oleh perusahaan.

\section{Konflik Peran}

Menurut Rina $(2017 ; 14)$ mengemukakan bahwa konflik adalah pertetangan yang terjadi dalam suatu organisasi dapat terjadi karena adanya perbedaan pendapat mengenai tujuan perusahaan, kompetisi antar departemen, antar bagian, antar unit kerja, para manajer yang bersaing dan berkonflik untuk memperebutkan posis dan kekuasaan

\section{METODE PENELITIAN}

Jenis penelitian yang digunakan dalam penelitian ini adalah penelitian explanatory menurut Sugiyono (2015:55) yaitu untuk mengetahui ada tidaknya hubungan antara variabel-variabel yang diteliti, sehubungan penelitian ini hanya bersifat menggambarkan suatu hubungan stres kerja dan konflik peran dengan kinerja pegawai pada Kantor Polsek Kecamatan Seluma Timur Kabupaten Seluma.

\section{Korelasi Rank Spearman}

Dalam korelasi rank spearman sumber data untuk kedua variabel yang akan dikonversikan dapat berasal dari sumber yang tidak sama, jenis data yang dikorelasikan adalah data ordinal, serta 
data dari kedua variabel tidak harus membentuk distribusi normal. Jadi korelasi rank spearman bekerja dengan data ordinal atau berjenjang atau rangking, dan bebas distribusi ( Sugiyono, 2015:245). Rumus korelasi spearman rank adalah :

$$
\rho=1-\frac{6 \sum b i^{2}}{n\left(n^{2}-1\right)}
$$

(Sugiyono, 2015:245)

Keterangan :

$$
\begin{array}{ll}
\rho & =\text { Koefisien Korelasi Spearman Rank } \\
\mathrm{n} & =\text { Jumlah sampel } \\
\sum b i^{2} & =\text { Jumlah kuadrat dari selisih rank variabel } \mathrm{X} \text { dan variabel } \mathrm{Y}
\end{array}
$$

\section{Pengujian Hipotesis}

Uji Hipotesis digunakan untuk mengetahui tingkat signifikansi dari korelasi, maka uji hipotesis yang digunakan adalah uji statistik uji t dengan rumus sebagai berikut :

$t_{\text {hitung }}=r \sqrt{\frac{n-2}{1-r^{2}}}$

(Sugiyono, 2015:251)

Keterangan :

$$
\begin{array}{ll}
t_{\text {hitung }} \quad=\text { nilai uji } \mathrm{t} \\
r \quad=\text { nilai koefisien korelasi } \\
\mathrm{n} \quad=\text { jumlah sampel }
\end{array}
$$

\section{HASIL DAN PEMBAHASAN}

\section{Analisa Korelasi Rank Spearman}

Hubungan Konflik peran Dengan Kinerja Pegawai Pada Kantor Polsek Kecamatan Seluma Timur Kabupaten Seluma

Untuk mengetahui hubungan konflik peran dengan kinerja pegawai pada Kantor Polsek Kecamatan Seluma Timur Kabupaten Seluma dianalisa dengan Korelasi rank spearman dengan rumus:

$\rho=1-\frac{6 \sum b i^{2}}{n\left(n^{2}-1\right)}$

Untuk menghitung korelasi rank spearman dibutuhkan tabel penolong korelasi rank spearman untuk hubungan konflik peran dengan kinerja pegawai pada Kantor Polsek Kecamatan Seluma Timur Kabupaten Seluma. Berdasarakan lampiran 8 di atas, maka dapat diketahui :

$$
\begin{aligned}
\mathrm{bi}^{2} & =7.653 \\
\mathrm{n} & =32
\end{aligned}
$$

Maka rekapitulasi korelasi rank spearman untuk hubungan konflik peran dengan kinerja pegawai pada Kantor Polsek Kecamatan Seluma Timur Kabupaten Seluma dapat diihitung sebagai berikut:

$$
\begin{aligned}
& \rho=1-\frac{6 \sum b i^{2}}{n\left(n^{2}-1\right)} \\
& \rho=1-\frac{6(7.653)}{32\left(32^{2}-1\right)}
\end{aligned}
$$




$$
\begin{aligned}
& \rho=1-\frac{45.918}{32(1.024-1)} \\
& \rho=1-\frac{45.918}{32(1.023)} \\
& \rho=1-\frac{45.918}{32.736} \\
& \rho=1-1.402 \\
& \rho=-0.403
\end{aligned}
$$

Diketahui bahwa besar korelasi konflik peran dengan kinerja pegawai pada Kantor Polsek Kecamatan Seluma Timur Kabupaten Seluma, adalah sebesar -0.403 .

Keterangan :

$0,00-0,199=$ Sangat rendah

$0,20-0,399=$ Rendah

$0,40-0,599=$ Sedang

$0,60-0,799=$ Kuat

$0,80-1,000=$ Sangat Kuat

( Sugiyono, 2013:184)

Artinya konflik peran dengan kinerja pegawai pada Kantor Polsek Kecamatan Seluma Timur Kabupaten Seluma, memiliki korelasi yang negative, karena nilai negative maka digunakan interprestasi yang paling rendah yaitu 0,00-0,199 dengan kriteria penilaian sangat rendah. Hal ini menunjukkan bahwa terdapat korelasi yang sangat rendah dan negatif antara konflik peran dengan kinerja pegawai pada Kantor Polsek Kecamatan Seluma Timur Kabupaten Seluma. Ini berarti semakin tinggi konflik peran maka akan semakin rendah kinerja pegawai pada Kantor Polsek Kecamatan Seluma Timur Kabupaten Seluma.

\section{Hubungan Stres Kerja Dengan Kinerja Pegawai Pada Kantor Polsek Kecamatan Seluma Timur Kabupaten Seluma}

Untuk mengetahui hubungan stres kerja dengan kinerja pegawai pada Kantor Polsek Kecamatan Seluma Timur Kabupaten Seluma dianalisa dengan Korelasi rank spearman dengan rumus:

$$
\rho=1-\frac{6 \sum b i^{2}}{n\left(n^{2}-1\right)}
$$

Untuk menghitung korelasi rank spearman maka dibutuhkan tabel penolong korelasi rank spearman untuk hubungan stres kerja dengan kinerja pegawai pada Kantor Polsek Kecamatan Seluma Timur Kabupaten Seluma, maka dapat diketahui:

$$
\begin{aligned}
\mathrm{bi}^{2} & =8.010 \\
\mathrm{n} & =32
\end{aligned}
$$

Maka korelasi rank spearman untuk hubungan stres kerja dengan kinerja pegawai pada Kantor Polsek Kecamatan Seluma Timur Kabupaten Seluma dapat diihitung sebagai berikut :

$$
\begin{aligned}
& \rho=1-\frac{6 \sum b i^{2}}{n\left(n^{2}-1\right)} \\
& \rho=1-\frac{6(8.010)}{32\left(32^{2}-1\right)} \\
& \rho=1-\frac{48.060}{32(1.024-1)}
\end{aligned}
$$


$\rho=1-\frac{48.060}{32(1.023)}$

$\rho=1-\frac{48.060}{32.736}$

$\rho=1-1,468$

$\rho=-468$

Diketahui bahwa besar korelasi stres kerja dengan kinerja pegawai pada Kantor Polsek Kecamatan Seluma Timur Kabupaten Seluma, adalah sebesar -468 .

Keterangan :

0,00-0,199 = Sangat rendah

$0,20-0,399=$ Rendah

$0,40-0,599=$ Sedang

$0,60-0,799=$ Kuat

$0,80-1,000=$ Sangat Kuat

( Sugiyono, 2013:184)

Artinya stres kerja dengan kinerja pegawai pada Kantor Polsek Kecamatan Seluma Timur Kabupaten Seluma, memiliki korelasi yang negative sehingga digunakan interpretasi nilai yang paling rendah yaitu 0,00-0,199. Hal ini menunjukkan bahwa terdapat korelasi yang sangat rendah dan negatif antara stres kerja dengan kinerja pegawai pada Kantor Polsek Kecamatan Seluma Timur Kabupaten Seluma. Ini berarti semakin tinggi stres kerja maka akan semakin rendah kinerja pegawai pada Kantor Polsek Kecamatan Seluma Timur Kabupaten Seluma.

\section{Pengujian Hipotesis}

Untuk menguji tingkat signifikansi korelasi rank spearman, maka dilakukan uji hipotesis statistik.

Hubungan Konflik peran Dengan kinerja Pegawai Pada Kantor Polsek Kecamatan Seluma Timur Kabupaten Seluma

Rumus yang digunakan untuk menguji hipotesis statistik dalam penelitian tentang hubungan konflik peran dengan kinerja pegawai pada Kantor Polsek Kecamatan Seluma Timur Kabupaten Seluma adalah uji t maka dapat diketahui :

$\mathrm{t}=-0.403$

$\mathrm{n}=32$

Rumus untuk uji $t_{\text {hitung }}$ adalah sebagai berikut

$t=t \sqrt{\frac{n-2}{1-r^{2}}}$

$t=-0.403 \sqrt{\frac{32-2}{1--0.403^{2}}}$

$t=-0.403 \sqrt{\frac{30}{1-162}}$

$t=-0.403 \sqrt{\frac{30}{0,838}}$

$t=-0.403 \sqrt{35,799}$

$t=-0.403(5,983)$

198 | Ngatimin, Ahmad Soleh, Abdul Rahman; Relationship Of Role Conflict And... 


\section{$t=-2,411$}

Dari hasil uji hipotesis diperoleh nilai thitung adalah -2,411. Karena nilai t hitung negative maka pengujian hipotesis dilakukan disisi kurva sebelah kiri kurva, bilangan negative t tidak bermakna minus (hitungan) tetapi mempunyai makna bahwa pengujian hipotesis dilakukan dari sisi kiri. Nilai $t_{\text {tabel }}$ dengan level of signifikan ditetapkan 95\% dengan perhitungan satu arah dan dk=n-2 = 32-2 = 30, maka diketahui nilai tabel sebesar 1,697 dengan kriteria ::

$\mathrm{H}_{02}$ : Konflik peran tidak mempunyai hubungan yang signifikan dengan kinerja pegawai pada Kantor Polsek Kecamatan Seluma Timur Kabupaten Seluma

$\mathrm{H}_{\mathrm{a} 2}$ : Konflik peran mempunyai hubungan yang signifikan dengan kinerja pegawai pada Kantor Polsek Kecamatan Seluma Timur Kabupaten Seluma

\section{Kesimpulan}

\section{KESIMPULAN DAN SARAN}

1. Konflik peran memiliki hubungan yang rendah dan negatif dengan kinerja pegawai pada Kantor Polsek Kecamatan Seluma Timur Kabupaten Seluma dengan nilai korelasi sebesar 0.403, berarti bahwa semakin tinggi konflik peran maka akan semakin menurun kinerja pegawai Kantor Polsek Kecamatan Seluma Timur Kabupaten Seluma. Hasil ini diperkuat dengan hasil uji hipotesis bahwa thitung sebesar $-2,411$ bernilai negative dan dilakukan pengujian hipotesis dari sisi kiri kurva maka thitung jatuh di area HO ditolak, dengan demikian $\mathrm{Ha}$ diterima. Dengan demikian hasil hipotesis adalah $\mathrm{H}_{01}$ ditolak dan $\mathrm{H}_{\mathrm{a} 1}$ diterima. Artinya konflik peran mempunyai hubungan yang signifikan dengan kinerja pegawai pada Kantor Polsek Kecamatan Seluma Timur Kabupaten Seluma.

2. Stres kerja memiliki hubungan yang sangat rendah dan negatif dengan kinerja pegawai pada Kantor Polsek Kecamatan Seluma Timur Kabupaten Seluma, dengan nilai korelasi sebesar -0,468, berarti semakin tinggi stres kerja maka akan semakin menurun kinerja pegawai pada Kantor Polsek Kecamatan Seluma Timur Kabupaten Seluma. Hal ini diperkuat dengan hasil uji hipotesis diketahui bahwa thitung sebesar -2,901 bernilai negative dan dilakukan pengujian hipotesis dari sisi kiri kurva maka thitung jatuh di area HO ditolak, dengan demikian Ha diterima. Artinya stres kerja mempunyai hubungan yang signifikan dengan kinerja pegawai pada Kantor Polsek Kecamatan Seluma Timur Kabupaten Seluma.

\section{Saran}

1. Diharapkan kepada pimpinan Kantor Polsek Kecamatan Seluma Timur Kabupaten Seluma agar membuat suatu job description yang lebih rinci, sehingga pegawai lebih mengetahui tugas dan tanggungjawabnya masing-masing.

2. Diharapkan kepada pegawai Kantor Polsek Kecamatan Seluma Timur Kabupaten Seluma untuk mampu menghadapi semua tantangan dalam bekerja, sehingga akan mengurangi stres kerja

\section{DAFTAR PUSTAKA}

Anoraga, 2017, Psikologi Indusrti dan Sosial. Jakarta: PT. Dunia Pustaka Jaya

Fufita, Yani. 2015. Hubungan Stress Kerja Dengan Kinerja Karyawan pada PT. Bank Bengkulu Cabang Manna. Skripsi. Universitas Dehasen Bengkulu

Gitosudarmo \& Sudita. 2016. Perilaku Keorganisasian, Edisi Pertama. Jogjakarta: Erlangga Handoko T. Hani, 2017. Manajemen Personalia dan Sumber Daya Manusia.BPFE : Yogyakarta Mahmudi. 2017. Manajemen Kinerja Sektor Publik. Yogyakarta:UPP AMP YKPN.

Mangkunegara. 2015. Manajemen Sumber Daya Manusia Perusahaan. Bandung: PT. Remaja Rosdakarya 
Moeheriono, 2016. Pengukuran Kinerja Berbasis Kompetensi. Bogor : Penerbit Ghalia Indonesia

Moeheriono, 2017. Pengukuran Kinerja Berbasis Kompetensi. Bogor: Ghalia

Nasution, Mulia, 2014, Manajemen Personalia, Djambatan, Jakarta

Pasolong, Harbani. 2016. Teori Administrasi Publik.. Yogyakarta: Alfabeta

Prawirosentono, Suryadi. 2015. Kebijakan Kinerja Karyawan. Yogyakarta:BPFE.

Rina, Handayani, 2017, Pengaruh Budaya Organisasi Dan Kepuasan Kerja Terhadap Kinerja Perusahaan Ditinjau Dari Perpektif Konsumen Dalam Balanced Scorecard (Studi Empiris Pada Perusahaan Consumer Goods Dan Perusahaan Jasa Di Semarang ). Unika Soegijapranata .

Rivai. Veithzal dan Mulyadi. Deddy, 2017, Kepemimpinan dan Perilaku Organisasi, Edisi Ketiga, Jakarta : Rajagrafindo Persada

Robbins, Stephen P. 2018. Perilaku Organisasi. Edisi ke-12, Jakarta: Salemba Empat.

Sastradipoera, Komaruddin. 2017. Pengembangan dan Pelatihan : Suatu Pendekatan Sumber Daya Manusia. Kappa Sigma. Bandung

Siagian, S.P. 2016. Teori dan Praktek Kepemimpinan, Penertbit Rineka Cipta Jakarta.

Sugiono, 2017, Manajemen Konflik dalam Organisasi, Bandung : Alfabeta

Sugiyono, 2015. Metode Penelitian Kunatitatif Kualitatif dan R\&D. Cetakan Ke-18 .Bandung Alfabeta.

Wijono 2014. Konflik Dalam Organisasi. Semarang: Satya Wacana

Yulizar, Okta, 2015, Hubungan Manajemen Konflik dengan Kinerja Pegawai Pada Puskesmas Bintuhan, Skripsi, Universitas Dehasen Bengkulu 